\title{
Comparative Studies on the Production of Biodiesel from Shea Nut Oil by Acid Catalyzed and Supercritical Transesterification Processes
}

\section{1*ODISU, T; ${ }^{2}$ AKEMU, A; ${ }^{2}$ OBAHIAGBON, KO; ${ }^{1}$ ANIH, EC}

\author{
${ }^{I}$ Department of Chemical Engineering, Federal University of Petroleum Resources, Effurun, Delta State, Nigeria, \\ ${ }^{2}$ Departments of Chemical Engineering, University of Benin, Benin City, Edo State, Nigeria \\ *Corresponding author: Odisu.teddy@fupre.edu.ng
}

\begin{abstract}
Shea nut oil has been confirmed as a feasible and sustainable biofuel source and may be used to improve the economics of biodiesel production. However, there is need to evaluate the best route for achieving optimum yield and best quality. Therefore, two processes were investigated in this study - acid catalyzed and supercritical transesterification processes. Shea nut seeds were collected, its oil mechanically extracted thereafter, and the physiochemical properties were analyzed. In the acid catalysed process, shea nut oil was transesterified into biodiesel using ethanol with sulphuric acid $\left(\mathrm{H}_{2} \mathrm{SO}_{4}\right)$ as a catalyst. This gave a conversion of between $55 \mathrm{wt} \%$ and $90 \mathrm{wt} \%$ for temperatures between $20^{\circ} \mathrm{C}$ and $90^{\circ} \mathrm{C}$. The optimum ratio of ethanol/oil was found to be $30: 1$ at $80^{\circ} \mathrm{C}$ for reaction time of 120 minutes. While for supercritical transesterification process (without acid), the conversion was between $55 \mathrm{wt} \%$ and $82.5 \mathrm{wt} \%$ at temperatures between $220^{\circ} \mathrm{C}$ and $300^{\circ} \mathrm{C}$. However, the optimum condition here was $20: 1$ ethanol/oil molar ratio, at $240^{\circ} \mathrm{C}$ and 24 minutes reaction time. The biodiesel properties produced were evaluated and most of these conformed to Biodiesel Standard, ASTM D6751 and the international standard, EN-14214. Also, the properties of Biodiesel produced by supercritical process seem better compared to that from the acid catalyzed process in line with the ASTM D - 6751 and EN-14214 standards, thus a better option for diesel engines making supercritical transesterification a preferred option for biodiesel production from shea nut oil.
\end{abstract}

\section{DOI: https://dx.doi.org/10.4314/jasem.v23i2.23}

Copyright: Copyright $(92019$ Odisu et al. This is an open access article distributed under the Creative Commons Attribution License (CCL), which permits unrestricted use, distribution, and reproduction in any medium, provided the original work is properly cited.

Dates: Received: 16 December 2018; Revised: 20 January 2019; Accepted 29 January 2019

Keywords: Sheanut, biodiesel, transesterification, acid-catalysed, supercritical, conversion

Over the years different researches into green energy sources have been majorly driven by the increasing energy demand and the perceived need to systematically lower the dependence on fossil fuels due to their relatively harmful effect on the environment (Abbaszaadeh et al, 2001). Biodiesel, fatty acid ethyl esters (FAEE) or fatty acid methyl esters (FAME), have been recognized as a relevant alternative fuel to mineral diesel (petroleum based), either as additive or as a whole replacement, because of the well-known environmental and relative economic benefits. Its merits include non-toxic, biodegradable, easy to produce (can even be domestically produced) and source renewability (Srivastava and Prasad 2000; Fukuda et al, 2001; Mahanta et al, 2006). Besides, this biofuel has cetane number higher than diesel from petroleum and can give a better combustion and emission profile. This includes reduced levels of particulate matter and carbon monoxide and, under some conditions, nitrogen oxides (Altin et al, 2001; McCormick et al, 2001; Mahanta et al, 2006). Moreover, the alkyl ester of fatty acids can be burned directly in unmodified diesel engines with very low deposit formation
(Badifu, 1989). The most common pathway used by many today in the production of biodiesel is the transesterification reaction which is conventionally performed using alkaline, acid or enzyme catalysts with the first two approaches widely preferred (Srivastava and Prasad , 2000: Audu , 2012). The conventional alkali catalyzed process results in high levels of conversion of triglycerides to their corresponding fatty acid alkyl esters in short reaction time. However, this comes with some disadvantages such as generation of large volume of waste water (Abbaszaadeh et al, 2001; Mahanta et al, 2006). Transesterification using acid catalysts is known to be much slower compared to that of alkali catalysis, and may give rise to undesirable bye-products, that may be difficult to separate. Also, the removal of catalyst from the biodiesel formed requires high degree of care since acid catalysts residues have the potential to damage engine parts. The above reason is the basis for very low maximum standard specification limit on acid value for final biodiesel product (Abbaszaadeh et al, 2001; Zhang et al, 2003).To reduce the drawbacks highlighted for catalyzed processes, a catalyst-free process for the transesterification of vegetable oils 
using an alcohol under supercritical conditions has been proposed, not undermining fuel quality and environmental concerns (Kusdiana and Saka, 2001; Demirbas, 2002).As highlighted above, the limitations of the acid based transesterification process will include its slow rate, undesirable bye products and challenges in spent catalyst recovery. Therefore, the need to try other means in the production of biodiesel particularly from shea nut oil becomes important.

It has been reported that catalyst-free alcoholysis reactions at high temperature and pressure can give improved phase solubility and decreased mass-transfer limitations. The reaction rate increases significantly in the supercritical state and thus the reaction is complete in less time with a resultant simpler separation and purification requirements (Kusdiana and Saka, 2001). In supercritical conditions, the alcohol substitute as reactant and acid catalyst and has been established that the supercritical method has better tolerance for the presence of water and free fatty acids than the conventional alkali-catalyzed processes (Kusdiana and Saka, 2004a). Hence the process is much more flexible to different types of vegetable oils, which has led to increase in research involving its application. The economic analysis of the processes for biodiesel production using homogeneous alkaline catalysis and supercritical method has been reported (Glisic and Skala, 2009; Deshpande et al 2010). Marchetti and Errazu (2008) evaluated different processes for biodiesel production using vegetable oils with high content of free fatty acids and stated that the supercritical method is an attractive alternative from a technological point of view. One of the promising sources of biodiesel production is the shea nut oil from shea tree (Vitellaria paradoxa). Shea tree produces the sheanut which can be processed into shea butter. The physicochemical properties of shea butter are comparable with the properties of groundnut oil which has been used in biodiesel production (Ogbonnaya and Adgidzi, 2008) and the properties of biodiesel are largely dependent on the physicochemical properties of the feedstock. Shea butter consists of $41.1 \%$ of saturated fatty acids and it has been observed that methyl esters of saturated fatty acids have a higher cloud point, Cetane number and better biodiesel stability (Ramadhas et al., 2005), (Sahoo et al., 2007) and biodiesel from Shea butter may less likely undergo oxidation since shea nut butter contains natural antioxidants such as tocopherols and some phenolic compounds (Maranz, 2004)

In the light of the above, this work compares side by side these two processes in focus - catalyzed and supercritical esterification in the production of biodiesel. The work also investigates the effect of process variables like temperature, time, catalyst concentration and molar ratios on the on the yield of biodiesel production from the two processes using sheanut oil.

\section{MATERIALS AND METHODS}

Sample Collection and Processing: Shear nuts (Butytrospermum parkii) were bought from Oba Market, Benin City, Edo State, Nigeria. The seeds were de- hulled to remove the outer seed coat. The dehulled seeds were then spread and dried under the sun for three consecutive days to reduce the moisture present in the seed. The dried seeds were size reduced with a mechanical grinder and sieved to get particle size in the range of $1-2 \mathrm{~mm}$.

Ground $15000 \mathrm{~g}$ of Shea nut seeds were placed inside a porous sack. The sack was placed inside a mechanical press where it was pressed to extract the oil. Standard analysis was also conducted on oil to determine its physicochemical properties.

Production of Biodiesel Using Supercritical Transesterification Process: The production of biodiesel using the supercritical esterification is a catalyst- free alcoholic reaction at high temperature and pressure. The procedure as described below (Ma and Hanna, 1999; Demirbas, 2002; Demirbas, 2003) was accompanied by variation in different process conditions like temperature, molar ratio and reaction time. Crude Shea nut oil $(100 \mathrm{ml})$ plus $414 \mathrm{ml}$ of ethanol at a molar ratio of 20:1 of ethanol/oil was transferred into a $500 \mathrm{ml}$ beaker. The mixture was stirred vigorously using electronic stirrer at a speed of 500 r.p.m for 20 minutes. The mixture was then transferred into a $500 \mathrm{ml}$ round bottom Pyrex flaskbatch reactor and heated at $220^{\circ} \mathrm{C}$ temperature for 24 minutes. The reaction product was allowed to stand for 3 hours to separate into two layers in a separating funnel. The tap of the separating funnel was opened to remove the dark brown layer of glycerol and the upper amber yellowish layer of ethyl ester was left in the separating funnel. The experiment was repeated at different temperature values of $230^{\circ} \mathrm{C}, 240^{\circ} \mathrm{C}, 250^{\circ} \mathrm{C}$,

$260^{\circ} \mathrm{C}, 270 \mathrm{C}, 280{ }^{\circ} \mathrm{C}$, and $300{ }^{\circ} \mathrm{C}$. The effect of reaction time (6 $\mathrm{min}, 9$ minutes, 12 minutes, 15 minutes, 18 minutes and 30 minutes; at a molar ratio of 6:1 ethanol/oil and $240{ }^{\circ} \mathrm{C}$ ) and ethanol/oil molar ratio $(3: 1.5: 1,6: 1,8: 1,10: 1,15: 1,25: 1$ and $30: 1$; at $240{ }^{\circ} \mathrm{C}$ for 24 minutes) on biodiesel yield was also investigated

Production of Biodiesel Using Acid Catalyzed Transesterification Process: Sulphuric acid $\left(\mathrm{H}_{2} \mathrm{SO}_{4}\right), 25 \mathrm{ml}$ of $3 \mathrm{M}$, was added to $124.2 \mathrm{ml}$ ethanol to form 
ethoxide. In this process (Fukuda, et al 2001), the ethoxide solution was added to $100 \mathrm{ml}$ of crude Shea oil at a molar ratio of $6: 1$ ethanol/oil and at varied reaction temperatures $\left(20{ }^{\circ} \mathrm{C}, 30{ }^{\circ} \mathrm{C}, 40{ }^{\circ} \mathrm{C}, 50{ }^{\circ} \mathrm{C}, 60\right.$ ${ }^{\circ} \mathrm{C}, 70{ }^{\circ} \mathrm{C}, 80{ }^{\circ} \mathrm{C}$, and $90{ }^{\circ} \mathrm{C}$ ). The final mixture was stirred and heated by a combined magnetic stirrer and a hot plate at a speed of 500 r.p.m for 60 minutes. A water-cooled condenser was mounted on the top of the flask to capture and return any vaporized alcohol. The reaction product was allowed to separate into two layers by standing for 12 hours (720 minutes) in a separating funnel. The tap of the separating funnel was opened to remove the dark brown layer of glycerol and the upper amber yellowish layer of ethyl ester was left in the separating funnel. The ethyl ester was washed four times with warm distilled water to remove residual alcohol. A small amount of pure glycerin was added to the ethyl ester and stirred for $15 \mathrm{~min}$. This glycerin was removed by gravity separation. It was found that this step helps to remove mono- and diglycerides. The effect of reaction time (20 minutes, 30 minutes, 40 minutes, 50 minutes, 60 minutes, 70 minutes 90 minutes, 120 minutes and 150 minutes; at a molar ratio of $6: 1$ ethanol/oil and $60^{\circ} \mathrm{C}$ ), ethanol/oil molar ratio $(1: 3,1: 5,1: 6,1: 10,1: 15,1: 20,1: 22.5$, $1: 30,1: 35$; at $60{ }^{\circ} \mathrm{C}$ for 60 minutes reaction time) and catalyst concentration $(0.25,0.5,0.8,1.0,1.5 .1 .8,2.0$, 2.25 , and $2.5 \%$; at a molar ratio of $6: 1$ ethanol/oil at 60 ${ }^{\circ} \mathrm{C}$ and for reaction time of 60 minutes) on biodiesel yield was also investigated.

\section{RESULTS AND DISCUSSION}

Table 1 shows the physicochemical properties of the extracted shea nut oil. It was observed that the percentage oil yield of Shea nut seeds obtained was 47 $\%$ as making shea nut a potentially good feedstock for biodiesel production. Also, other properties analyzed for like free fatty acid (18.02\%) and presence of water $(0.6 \%)$ makes shea nut oil a good feedstock for transesterification process.

Table 1: Physiochemical properties of shea nut oil from mechanical expression

\begin{tabular}{ll}
\hline Properties & Values \\
\hline Specific gravity & 0.8664 \\
$\%$ Moisture content & 0.6 \\
Acid value $(\mathrm{mg} \mathrm{NaOH} / \mathrm{g}$ oil) & 36.04 \\
Free fatty acid value $(\%)$ & 18.02 \\
Iodine value (gram Iodine/100g oil) & 7.11 \\
Saponification value $(\mathrm{mg} \mathrm{NaOH} / \mathrm{g}$ oil) & 196.40 \\
Ash content & 1.00 \\
Cloud point $\left({ }^{\circ} \mathrm{C}\right)$ & 29 \\
Pour point $\left({ }^{\circ} \mathrm{C}\right)$ & 27 \\
Refractive index & 1.466 \\
Viscosity $(\mathrm{cP})$ & 2.8 \\
Flask point $\left({ }^{\circ} \mathrm{C}\right)$ & 340 \\
Yield of shea nut seeds $(\%)$ & 47 \\
\hline
\end{tabular}

Figure 1 to 3 above show the effect of ethanol/oil molar ratio, temperature and time on the percentage yield of ethyl ester using the supercritical transesterification process. In determining the effect of molar ratio on the yield, molar ratio was varied from 3:1 to $35: 1$ while keeping all other process variables constant. Ethanol/oil molar ratio is one of the important variables affecting the yield of fatty acid ethyl ester because an increase in Ethanol/oil molar ratio should allow greater contact between ethanol and oil thus favoring conversion (Kusdiana and Saka, 2001). From the study, it was observed that the yield of ethyl ester increased with increase in molar ratio with the optimum molar ratio being 20:1 for the supercritical method.

The effect of temperature on the yield of ethyl ester is shown in figure 2 . The temperature was varied while keeping other process variables constant. Studies in literature show that reaction temperature is the critical parameters for determining the extent of reaction especially across the critical temperature of ethanol which is $240{ }^{\circ} \mathrm{C}(514 \mathrm{~K})$.

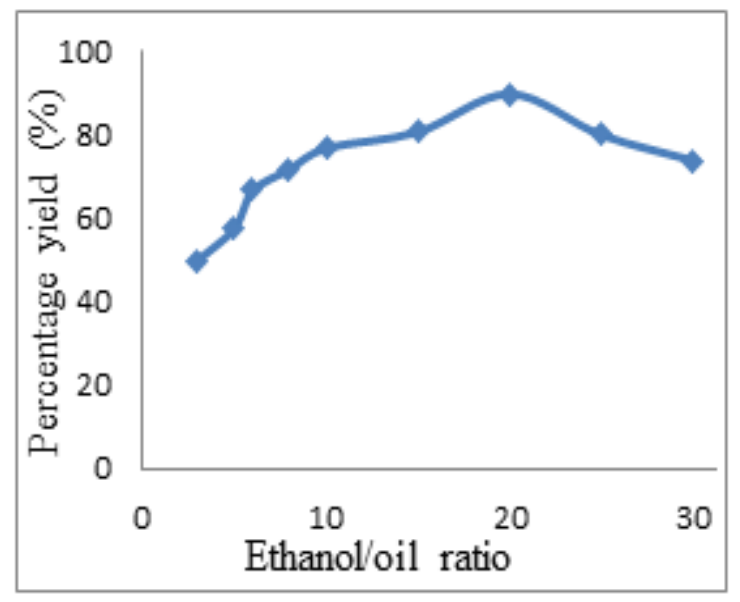

Fig 1: Effect of molar ratio on the yield of ethyl ester

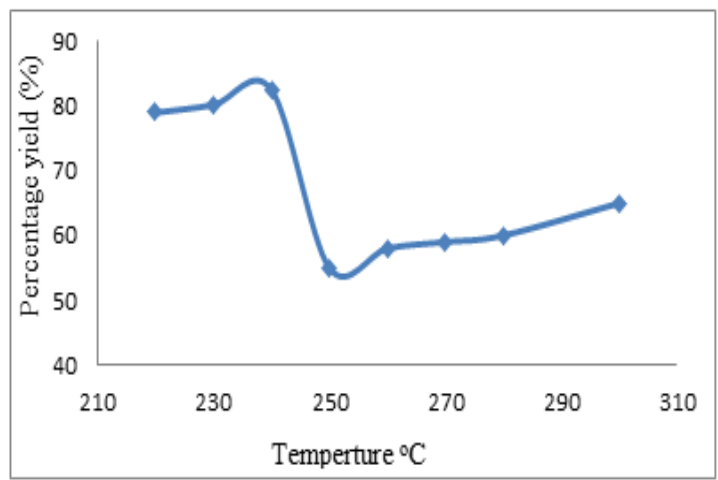

Fig 2: Effect of temperature on percentage yield of ethyl ester 


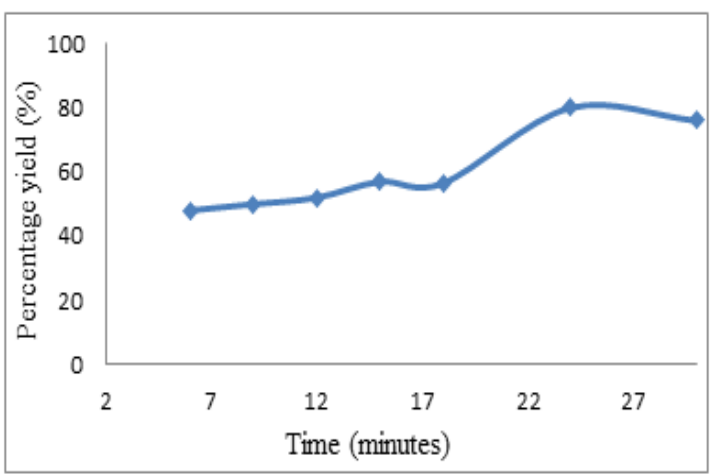

Fig 3: Effect of time on percentage yield of ethyl ester

Generally, an increase in reaction temperature resulted in a sharp enhancement of reaction conversion and faster reaction rate but at temperatures greater than $240{ }^{\circ} \mathrm{C}$, a decrease in reaction yield was observed. At temperature $220{ }^{\circ} \mathrm{C}$ and $230{ }^{\circ} \mathrm{C}$ the conversion of triglycerides to ethyl ester was relatively low due to the subcritical state of ethanol while at temperature of $250{ }^{\circ} \mathrm{C}, 260{ }^{\circ} \mathrm{C}, 270{ }^{\circ} \mathrm{C}, 280{ }^{\circ} \mathrm{C}, 290{ }^{\circ} \mathrm{C}$, and $300{ }^{\circ} \mathrm{C}$ there was a decrease in the ethyl ester yield. This could be as a result of the decrease in the content of unsaturated ethyl ester caused by isomerization, hydrogenation, and thermal decomposition that consume ethyl ester especially $\mathrm{C}_{18}: \mathrm{O}_{2}$ (Linoleic) and $\mathrm{C}_{18}: \mathrm{O}_{2}$ (Oleic) that are more susceptible to thermal decomposition compared to mono-unsaturated and saturated ethyl ester (Damoko and Cheryan, 2000). The optimum reaction temperature for supercritical transesterification was $240{ }^{\circ} \mathrm{C}$.

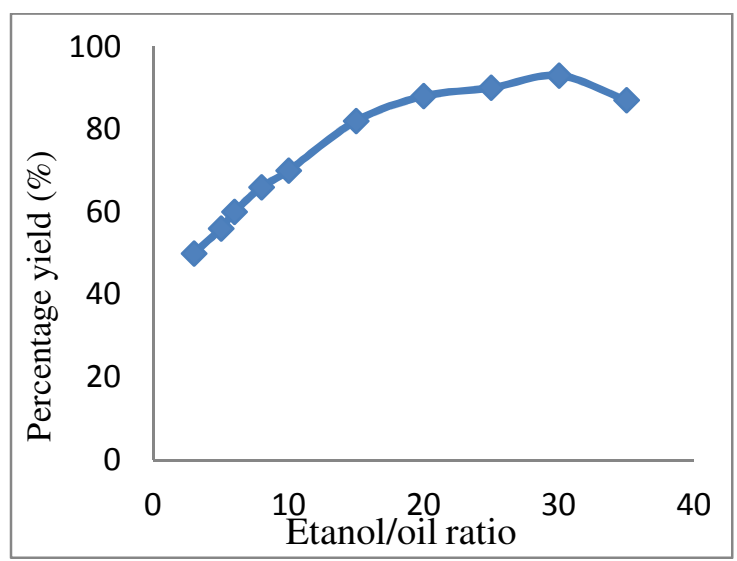

Fig 4: Effect of molar ratio on the yield of ethyl ester

Figure 3 gives a captures the effect of reaction time on the yield of ethyl ester by varying time and keeping other process variables constant. The results revealed that the yield of ethyl ester increased with increasing reaction time. The optimum reaction time was 24 minutes for the supercritical transesterification. From this research it was observed that the best operating parameters (strategy) to produce ethyl ester from shea nut oil by supercritical method is by using 20:1 ethanol/oil molar ratio, at a reaction temperature of $240{ }^{\circ} \mathrm{C}$ and 24 minutes reaction time

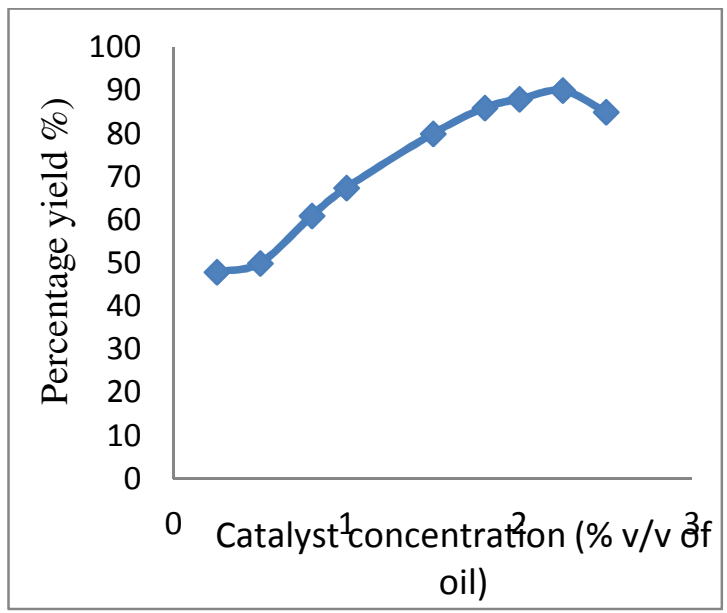

Fig 5: Effect of catalyst concentration on the yield of ethyl ester

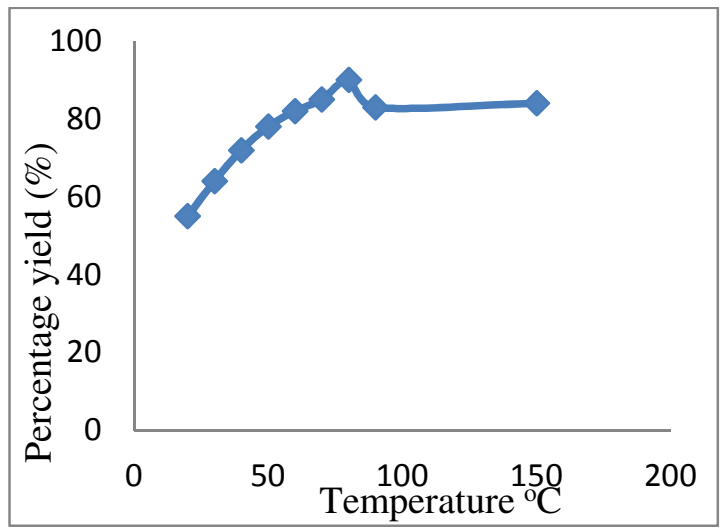

Fig 6: Effect of temperature on the yield of ethyl ester

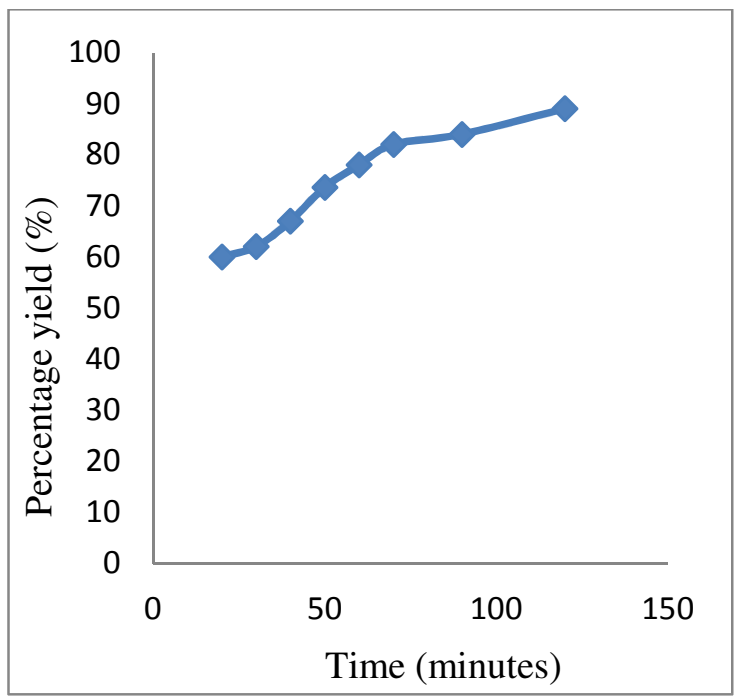

Fig 7: Effect of time on the yield of ethyl ester 
Figure 4 to 7 show the effect of ethanol/oil molar ratio, temperature and reaction time on the percentage yield of ethyl ester using the acid catalyzed process. To determine the effect of ethanol/oil molar rail on the yield (figure 4), the molar ratio was varied from 3:1 to 35:1 while keeping all other process parameters constant. As mentioned above, ethanol/oil molar ration is a very important factor affecting the yield of ethyl ester even in the acid catalyzed process because an increase in the molar ratio result in increase in conversion (Kusdiana and Saka, 2001). The optimum molar ratio for the acid catalyzed process was observed to be $30: 1$.

Figure 5 shows the effect of catalyst concentration on the yield of ethyl ester for the acid catalyzed process. It is general knowledge that catalyst can affect the rate of a chemical reaction either positively or negatively. From the figure, the yield of was positively affected as increase in the catalyst concentration from $0.25(\% \mathrm{v} / \mathrm{v}$ of oil) to 2.5 (\% v/v of oil) resulted in yield of $48 \%$ to $90 \%$ with an optimum catalyst concentration of 2.25 corresponding to a yield of $90 \%$. It was also noticed that beyond the $2.25(\% \mathrm{v} / \mathrm{v}$ of oil $)$ catalyst concentration, the yield started to drop. Thus with a

catalyst concentration of $2.5(\% \mathrm{v} / \mathrm{v}$ of oil) a yield of $85 \%$ was recorded.

Figure 6 relates the effect of temperature on the ethyl ester yield. In this study, the temperature was varied from $20^{\circ} \mathrm{C}$ to $150{ }^{\circ} \mathrm{C}$ while keeping other parameters constant. It is a general knowledge that temperature increase results in enhancement of reaction conversion and faster reaction rate this was also the case in the acid catalyzed method. While in the supercritical esterification certain temperatures points resulted in negative outcomes, in the acid catalyzed transesterification method, the reaction temperature was not high enough to cause thermal decomposition, the optimum reaction temperature was observed to be $80^{\circ} \mathrm{C}$. Lastly, figure 7 shows the effect of time on the yield of ethyl ester. In carrying out this study, time was varied while other parameters where kept constant. It was observed that as reaction time increased, ethyl ester yield also increased with an optimum reaction time of 120 minutes as against 24 minutes for supercritical esterification method. This study showed that the best operating parameters (strategy) to produced ethyl ester from shea nut oil by acid catalyst method is by using 30:1 ethanol/oil molar ratio at a reaction temperature of $80^{\circ} \mathrm{C}$ and 120 minutes reaction time.

Table 2: Physiochemical Properties of Ethyl Ester Produced by both Processes (Super Critical Process and Acid Catalyst Process) in

\begin{tabular}{|c|c|c|c|c|c|}
\hline Parameter/Unit & $\begin{array}{l}\text { Super } \\
\text { Critical Ethyl } \\
\text { Ester } \\
\text { Values }\end{array}$ & $\begin{array}{l}\text { Acid } \\
\text { Catalyst } \\
\text { Ethyl Ester } \\
\text { Values } \\
\end{array}$ & $\begin{array}{l}\text { ASTM } \\
\text { Specifications } \\
\text { (D6751) }\end{array}$ & EN 14214 & $\begin{array}{l}\text { N0.2 } \\
\text { DIESEL }\end{array}$ \\
\hline S.G. $60 / 60^{\circ} \mathrm{F}$ & 0.870 & 0.867 & $0.80-0.90$ & $1.9-6.00$ & $820-860$ \\
\hline Acid Value $\mathrm{mgNaOH} / \mathrm{g}$ & 0.35 & 0.4 & & 0.5 & _- \\
\hline Cloud point $\left({ }^{0} \mathrm{C}\right)$ & 32 & 15 & & & -19 to -8 \\
\hline $\begin{array}{l}\text { Kinematic viscosity } \\
@ 40^{\circ} \mathrm{C}\left(\mathrm{mm}^{2} / \mathrm{s}\right)\end{array}$ & 5.92 & 5.6 & $1.9-6.0$ & $3.5-5.0$ & $2.5-3.5$ \\
\hline Pour point $\left({ }^{\circ} \mathrm{C}\right)$ & 28 & 12 & & & -34 to -10 \\
\hline Cetane number & 53.26 & 48 & 47 & 51 & $49-55$ \\
\hline Flash point $\left({ }^{\circ} \mathrm{C}\right)$ & 173.5 & 178 & 130 & $>101$ & $>55$ \\
\hline Copper strip Corrosion & $3 a$ & $3 a$ & 3 & & \\
\hline
\end{tabular}

The biodiesel produced using the above optimum operating parameters were analyzed with respect to some significant properties of diesel fuel. Most of these properties conformed to Biodiesel Standard, ASTM D-6751, and the international standard, EN 14214 as shown in table 2, except for the cloud point and pour point where ethyl ester showed higher values which may have resulted from high Pamitic, Arachidic and Stearic acid content of Shea nut oil, (shea nut oil consist $42.4 \%$ of saturated palmitic acid, Arachidic acid and stearic acid). This position is hinged on the fact that it has been established that the saturated components increases the cloud point and pour point of biodiesel (Bamgboye and Hansen, 2008). While most of the fuel properties of ethyl ester produced are comparable to petroleum- based diesel fuel, improvement of its low temperature flow characteristic still remain one of the major challenges when using biodiesel as an alternative fuel diesel engines. Crystallization of the saturated fatty acids of the biodiesel during cold season causes fuel starvation and operability problems as solidified materials clog lines and filter (Mulugetta 2008). In order for this diesel to be adopted as a substitute to petroleum-based diesel, the fuel line should be line with a heater to maintain acceptable viscosity of the diesel. It has also been established that the addition of ethanol in biodiesel helps to reduce the kinematics viscosity of biodiesel (McCormick et al, 2001) Biodiesel having high cloud point and high pour point can be used in tropical and temperate regions.

The flash point is a parameter that determines the safety of fuel during its handling and storage. It is the 
lowest temperature at which the vapours above the fuel become flammable. The flash point, therefore, specifies the temperature to which a fuel needs to be heated for spontaneous ignition of the vapour and air above the fuel to occur. The flash point of the biodiesel produced by both production processes were $173.5^{\circ} \mathrm{C}$ and $178{ }^{\circ} \mathrm{C}$ for supercritical and acid catalyzed and these met the ASTM specifications D6751 $\left(\geq 130^{\circ} \mathrm{C}\right)$, EN14214 specifications of $\left(>101{ }^{\circ} \mathrm{C}\right)$ and Number 2 Diesel $\left(>55^{\circ} \mathrm{C}\right)$. Furthermore, the specific gravity of biodiesel produced by both production processes were 0.87 and 0.867 for supercritical and acid catalyzed and these met the ASTM specification D6751 (0.80-0.90). The acid value of the biodiesel by supercritical process $(0.35 \mathrm{mgNaOH} / \mathrm{g})$ and acid catalyzed process $(0.4$ $\mathrm{mgNaOH} / \mathrm{g})$ met the EN14214 specification $(\leq 0.5$ $\mathrm{mgNaOH} / \mathrm{g}$ ). Transesterification using acid catalysts is known to have difficulty in separation steps, and requires careful removal of catalyst from the biodiesel fuel since acid catalyst residues can damage engine parts (Zhang et al, 2003; Abbaszaadeh et al, 2008) This is one of the main reasons why most biodiesel standard specifications place a very low maximum limit on acid value for the final product. Viscosity is a measure of the internal flow resistance of a liquid. Viscosity affects injection, lubrication and fuel atomization. High viscosity fuel has the tendency of forming engine deposits. The kinematic viscosity of the biodiesel produced by supercritical $\left(5.92 \mathrm{~mm}^{2} / \mathrm{sec}\right)$ and acid catalyst $\left(5.6 \mathrm{~mm}^{2} / \mathrm{sec}\right)$ and these met the ASTM specifications D6751 (1.9-6.0) $\mathrm{mm}^{2} / \mathrm{sec}$. This indicate that both biodiesel produced can effectively be used in diesel engines since they perfectly satisfy the fluidity requirements of alternative biodiesel fuel. Cetane number is an indicator of the combustion speed of diesel fuel. It is an inverse of the similar octane rating for gasoline (petrol). Cetane number is an important factor in determining the quality of diesel fuel. The cetane number of the biodiesel produced by both production processes were supercritical (53) and acid catalyzed (48) and these met the ASTM specifications D6751 ( $\geq 47)$, but were found to be close to EN14214 specification $(\geq 51)$ and close to Number 2 Diesel specification ( $>55)$. Biodiesel produced by supercritical trans-esterification process have higher cetane number, better acid value and improve flash point value than biodiesel produced by acid catalyzed trans-esterification process.

Conclusion: Conclusively, from the results obtained in this research, it has been observed that supercritical trans-esterification method proved to be a better approach for the production of biodiesel from shea nut oil considering the properties of produced biodiesel using both approaches. Therefore, it is here suggested that in future production of biodiesel from shea nut oil, supercritical trans-esterification method should be employed.

\section{REFERENCES}

Abbaszaadeh, A; Ghobadian, B; Omidkhah, MR; Najafi, G (2008). Current biodiesel production technologies: A comparative review. Ener. Conver and Manage, 63, pp 138-148

Altin, R; Çetinkaya, S; Yucesu HS (2001). The potential of using vegetable oil fuels as fuel for diesel engines. Ener. Conver and Manage, 42, pp 529-538.

Audu TOK (2012). Development of a viable Technology for the Production of Biodiesel from Oils of non- edible seeds. PTDF Professorial Chair Lecture Series University of Benin Press, Benin City, Nigeria.

Badifu GIO (1989). Lipid Composition of Nigerian Butyrospermum paradoxum kernel. J. of Food Compos. Analys. 2, pp 238-244.

Bamgboye, AI; Hansen, AC (2008). Prediction of Cetane Number of Biodiesel Fuel from the Fatty Acid Methyl ester Composition. Inst. of Agrophys. 22, pp 21-29.

Demirbas A (2002). Biodiesel from vegetable oils via transesterification in supercritical methanol. Ener. Convers. Manage. 43 pp 2349-2356

Demirbas A (2003). Biodiesel fuels from vegetable oils via catalytic and non- catalytic supercritical alcohol transesterifications and other methods: a survey. Ener. Convers. Manage,, 44 pp 20932109

Deshpande, A; Anitescu, G; Rice, P. A; Tavlarid es, L L (2010). Supercritical biodiesel production and power cogeneration: Technical and economic feasibilities. Biores. Tech., 101, pp 1834-1843.

Freedman, B; Pryde EH; Mounts TL (1984). Variables affecting the yields of

fatty esters from transesterified vegetable oils. $J$. of Amer. Oil Chemists Soc. 61, pp 1638-43.

Fukuda, H., Kondo, A. and Noda, H. (2001). Biodiesel fuel production by transesterification of oils. $J$. of Bioscie. and Bioeng. 92, pp 405-416.

Gerpen J V (1997). Biodiesel processing and production. Fuel Pro. Tech. 86, pp 1097-107. 
Glisic, S; Skala, D (2009). The problems in design and detailed analyses of energy consumption for biodiesel synthesis at supercritical conditions. The J. of Supercri. Fluids, 49, pp 293-301.

Kusdiana, D; Saka, S (2001). Biodiesel fuel from rapeseed oil as prepared in supercritical methanol. Fuel, 80, pp 25-231.

Kusdiana, D; Saka, S (2004a). Effects of water on biodiesel fuel production by supercritical methanol treatment. Biores. Tech., 91, pp 289295.

Lang, X; Dalai, AK; Bakhshi, NN; Reaney, MJ; Hert, PB (2001). Preparation and characterization of biodiesels from various bio-oils. Biores. Tech., 80, pp 53-62.

Ma, F; Hanna, MA (1999). Biodiesel production: a review. Biores. Tech., 70:pp1-15.

Mahanta, P; Mishra, SC; Kushwash, YS (2006). An Experimental Study of Pongamia Pinnata L. Oil as a Diesel Substitute. J. of Pow. and Ener., 220 pp 803- 808.

Maranz, SZ; Wiesman, J; Bisgaard, J; Bianchi, G (2004). Germplasm resources of Vitellaria paradoxa based on variations in fat composition across the species distribution range. Agrofor. Sys., 60, pp 71-76.

Marchetti, JM; Errazu, AF (2008). Technoeconomic study of supercritical biodiesel production plant. Ener. Convers. and Manage., 49, pp 2160-2164.
McCormick, R L; Graboski, MS; Alleman, T L; Herring, AM (2001). Impact of biodiesel source material and chemical structure on emissions of criteria pollutants from a heavy-duty engine. Environ. Sci. and Tech., 35, pp 1742-1747.

Mulugetta, Y (2008). Evaluating the economics of biodiesel in Africa. Renew. and Sust. Ener. Rev., 13, pp 1592-15989

Ogbonnaya, C; Adgidzi, PP (2008). Evaluation of some physicochemical properties of shea butter (Butyrospermum paradoxum) related to its value for food and industrial utilization. Inter. J. of Posthar. Tech. Inn., 1(3), pp 320-326.

Ramadhas, AS; Jayaraj, S; Muraleedharan, C (2005). Biodiesel production from high FFA rubber seed oil. Fuel, 84, pp 335-340.

Sahoo, PK; Das, LM; Babu, MKG; Naik, SN (2007). Biodiesel development from high acid value polanga seed oil and performance evaluation in a CI engine. Fuels, 86, pp 448-454.

Srivastava, A; Prasad, R (2000). Triglycerides-based diesel fuels. Renew. and Sus. Ener. Rev., 4, 111133

Zhang, Y; Dubé, MA; MClean, DD; Kates, M (2003). Biodiesel production from waste cooking oil. Biores. Tech., 89, pp 1-16.

Darnoko, D; Cheryan, M (2000). Kinetics of Palm Oil Transesterification in a Batch Reactor. J. of Ame. Oil Chem.' Soc. 